\title{
DIAMETER STRUCTURE AND PHYTOSOCIOLOGICAL FREQUENCY OF A “TERRA FIRME” AMAZON FOREST, BEFORE AND AFTER SELECTIVE CUTTING
}

\author{
Ulisses Silva da Cunha ${ }^{1}$, Sebastião do Amaral Machado ${ }^{2}$, Afonso Figueiredo Filho ${ }^{3}$, \\ Joberto Veloso de Freitas ${ }^{1}$ \\ ${ }^{1}$ Forest Engineer, Dr., Dep. of Forest Sciences, UFAM, Manaus, AM, Brazil - ulisses@ufam.edu.br; joberto@ufam.edu.br \\ ${ }^{2}$ Forest Engineer, Dr., Dep. of Forest Sciences, UFPR, Curitiba, PR, Brazil - samachado@ufpr.br \\ ${ }^{3}$ Forest Engineer, Dr., Dep. of Forest Engineering, UNICENTRO, Irati, PR, Brazil - afig@ufpr.br \\ Recebido para publicação: 05/05/2011 - Aceito para publicação: 30/11/2011
}

\begin{abstract}
This article aims to characterize horizontal and diameter structure of a managed forest using graphic expression techniques. Data for this research is result of complete forest inventory (census) carried out from a block of 800 hectares, before and after selective cutting, inside Tapajós National Forest, located in the Municipality of Belterra, State of Pará, Brazil. The analysis revealed that, in relation to horizontal structure, intense cutting resulted in changes of different levels mainly to phytosociological frequency of some species, such as, Manilkara huberi, Carapa guianensis and Tabebuia serratifolia. The diameter structure of some species, such as Sextonia rubra and Dipteryx odorata, revealed changes after selective cutting under technically acceptable rates, because the stock levels of some diameter classes surpassed the limits of balance observed for polycyclic systems with silviculture based on natural regeneration. The inclusion of graphics in the harvest operating plan for the 10 most important species listed in forest management, that is, before and after selective cutting, would lead to the desirable structure maintenance.

Keywords: Diameter distribution; cutting cycle; forest management; Amazonian forest; graphic techniques.
\end{abstract}

\section{Resumo}

Estrutura diamétrica e frequência fitossociológica de uma Floresta de Terra Firme da Amazônia brasileira antes e depois do corte seletivo. O objetivo da presente pesquisa foi caracterizar a estrutura horizontal e diamétrica de uma floresta manejada usando técnicas de expressão gráfica. Os dados provieram de um inventário florestal sob completa enumeração (censo) efetuado em um bloco de 800 hectares, antes e depois de um corte seletivo dentro da Floresta Nacional do Tapajós, localizada no município de Belterra, Pará. As análises mostraram que a intensidade de corte utilizada promoveu diferentes níveis de alteração na estrutura horizontal, com mudanças mais significantes nas taxas de frequência fitossociológica de algumas espécies, tais como Manilkara huberi, Carapa guianensis e Tabebuia serratifolia. A estrutura diamétrica de algumas espécies, tais como Sextonia rubra e Dipterix odorata, apresentou alterações após o corte seletivo acima de taxas tecnicamente aceitáveis, porque o nível de estoque de algumas classes de diâmetro ultrapassou limites de balanço observado para sistemas policíclicos com silvicultura baseada na regeneração natural. A inclusão de gráficos no plano de operação de colheita para as 10 espécies mais importantes listadas no manejo, isto é, antes e depois do corte seletivo, induziria à estrutura desejada a ser mantida.

Palavras-chave: Distribuição de diâmetro; ciclo de corte; manejo florestal; Floresta Amazônica; técnicas gráficas.

\section{INTRODUCTION}

In spite of researchers efforts, available data quantity and quality have been a major limitation for consistent research in the Amazon Forest. Likewise, there are few experimental established areas with the purpose of providing support for the development of methodologies used in the region. Such situation reveals the importance of pilot projects development by environmental organs in order to stimulate 
research in the region.

Information about diameter structure would allow a better understanding about product stock levels, making easy the organization of logistic operations within the Annual Production Unit (APU) plan. For this research, diameter structure and phytosociological frequency aspects have been studied in a "Terra Firme" forest, using modern graphical construction and representation techniques.

Diameter structure of a tropical forest is understood here as an essential prerequisite for planning and carrying out management projects. The most important parameter for description of any forest development is the variable age, which is difficult to determine for tropical forests. This implies that such difficulty for determining ages in a climax community with an ample range of ages, such as for a tropical forest, should also be compensated by an analysis of the forest diameter structure.

The diameter distribution that guarantees a forest species survive, as well as its rational use under a regime of a sustainable yield, is, no doubt, the "regular diameter distribution", whose premise is that inferior classes should maintain a larger number of individuals in order to compensate reduction by harvest or natural mortality in the class change transition process. The species that present a non-regular diameter distribution are at a disadvantage in surviving dispute even in mature growth state (FINOL, 1964).

Many researches on diameter distribution have been carried out in the Amazon Forest, several in Tapajós National Forest, as the researches by Barros et al. (1979), by Carvalho (1981), and a very important one by Silva (1989). Besides these pioneer researches other important and more recent ones are those developed by Jardim and Hosokawa (1987), Umaña and Alencar (1998), Cunha (2003), Azevedo et al. (2007), Vasconcelos (2003), Vasconcelos et al. (2009), Francez et al. (2009), as well as many other researches developed based on data from different sites of the Amazon Forest.

This research aims to characterize the diameter structure and phytosociological frequency of a natural tropical forest in the Amazon, before and after selective cutting, based on information from a $100 \%$ inventoried forest, as well as to test graphic analysis employed to harvest operation plan.

\section{MATERIAL AND METHODS}

Database for this survey are from an 800 hectares area located within the Tapajós National Forest, in the State of Pará - Brazil. This area was divided in 8 blocks of 100 hectares each, measuring $1000 \mathrm{~m} \mathrm{x}$ $1000 \mathrm{~m}$, for better exploitation control. All trees with a diameter at breast height $(\mathrm{DBH}) \geq 35 \mathrm{~cm}$ had been measured, in a total of 16,630 trees. This area was exploited under control of harvested trees, basal areas and removed volumes.

The forest management of this area was carried out as a part of the pilot program for tropical forests of the cooperation agreement signed by the "Instituto Brasileiro do Meio Ambiente" (IBAMA) and the "International Tropical Timber Organization" (ITTO) (1997), following the IBAMA's Normative Instruction 4 (IBAMA, 2002).

Before the analysis itself, the diameters had been grouped in variable amplitude classes, using the Q3-Q1 method proposed by Cunha et al. (2003). The Q3-Q1 method is an alternative for data grouping that uses the quartile concept. The formula $Q 3-Q 1$ is:

$$
k=\operatorname{Ln}[(Q 3-Q 1) \times n]
$$

Where: $k=$ number of classes;

$n=$ number of observations

$Q_{1}, Q_{3}=$ first and third quartiles, respectively

Interquartile range was chosen for the equation due to the fact that the already carried out studies have proven their efficiency as applied to populations containing at least 30 observed individuals (CUNHA et al., 2003).

The histograms with varied sizes classes had been directly processed using a basic computer program module - $\mathbb{R}$. It should be highlighted that conventional statistical computer programs, such as, STATISTICA, SPSS, STATGRAPHICS, MINITAB, as well as spreadsheet programs as Excel do not have easy access tools that allow construction of graphics by automatic computer devices. 
In order to make analysis easier, including a variable indirect obtained, as the determination of the phytosociological frequency, each Hectare Basic Unit (HBU) was coded with a sequential number $\mathrm{j}:(1,2,3 \ldots, 800)$, reaching all the numbered 800 hectares. Rather then, each variable was preliminarily computed for each HBU, allowing an overall computation of averages as well as scoring of species, hectares or area fraction or total.

The phytosociological frequency $(\%)$, differently from abundance $\left(\mathrm{n}_{\mathrm{i}}\right.$ per hectare), describes spatial distribution on a land area of a specific species in relation to an inventoried area. Before proceedings for phytosociological frequency calculation, it is necessary to divide the area into basic hectare units of same form or dimensions, in order to use each unit as sample until fill in $100 \%$ of the observed area. The abundance, in its turn, quantifies only a specific species individual's number or individual's total number per unit area.

If a 100 hectare area is divided into 100 equal parts of one hectare, assuming that the presence of a determined species is found in 25 of these parts whatever the order, totaling 30 individuals, then the absolute phytosociological frequency would be $25 \%$ and the abundance would be thirty trees per 100 hectares.

The phytosociological frequency according to Finol (1964) is considered as an important variable in allowing the evaluation of the quantification of altered spaces in a managed primary forest, for example, and is estimated as:

$$
F F[i] \text { abs }(\%)=\frac{\sum_{j}^{m} B[i]_{j}}{\text { Total number of modules }} \times 100 \quad F F[i] \operatorname{rel}(\%)=\frac{F F[i] a b s}{\sum_{j=1}^{m} F F_{i j} a b s} \quad\left\{\begin{array}{l}
j=1,2, \ldots, m \\
i=1,2, \ldots, n
\end{array}\right.
$$

Where: $B[i]_{j}=0$ (absence) or 1 (presence)

$F F[i] a b s(\%)=$ absolute phytosociological frequency for the $i^{\text {th }}$ species

$B[i]_{j}=$ number of modules recorded with the presence of the $\boldsymbol{i}^{\text {th }}$ species

$F F[i]$ rel $(\%)=$ relative phytosociological frequency of $\boldsymbol{i}^{\text {th }}$ species

$F F_{i j} a b s(\%)=$ absolute phytosociological frequency of the $i^{\text {th }}$ species in the $j^{\text {th }} 1$ hectare module.

A managed primary forest is understood as a part of the ecosystem submitted to silviculture at a specific time, aiming to a sustained production of timber or other products in successive cutting cycles. In order to adjust the probability density curve (Figure 1b), the S-Plus plot (density) function was used with the Gaussian adjustment parameter.

\section{RESULTS AND DISCUSSION}

The results of processed data are summarized in three tables and seven figures. Both the tables and figures contextualize the variables before and after selective cutting. The sequence of the tables attempts to illustrate the abundance behavior, phytosociological frequency, basal area and volume within a real scenario of forest management. The sequence of figures is predominately formed by abundance, diameter distributions by species, before and after selective cutting, and finally the basal area distribution profile by diameter class.

The tables allow individual behavior better understanding of the species under analysis, as well as their main behavior in relation to the other harvested species in terms of abundance, phytosociological frequency, basal area and volume. The figures, as incorporating the most modern graphic representation techniques, highlight aspects that are normally omitted during traditional analysis, such as, real time visualization of the diameter class limits in varied sizes and histogram adjustment, which enables a view before and after selective cutting.

Table 1 presents abundance, basal area and volume for the 195 species inventoried in the 800 hectares, before and after the selective cutting, and the ones removed by harvest, considering trees with a 
$\mathrm{DBH} \geq 35 \mathrm{~cm}$. This table reveals that before selective cutting there was an average of 27 trees per hectare with a DBH $\geq 35 \mathrm{~cm}$, with up to 84 trees per hectare in several one Hectare Basic Units (HBU), the average basal area was $9.71 \mathrm{~m}^{2}$ per hectare, with up to $25.35 \mathrm{~m}^{2}$ per hectare in several HBU's and the average volume was $95.01 \mathrm{~m}^{3}$ per hectare, reaching up to $271.2 \mathrm{~m}^{3}$ per hectare in several HBU's.

Table 1. Abundance (A), basal area (G) and volume (V) per hectare for trees with $\mathrm{DBH} \geq 35 \mathrm{~cm}$ before, after, and harvested during selective cutting, for the 195 species inventoried in the 800 hectares.

Tabela 1. Abundância (A), área basal (G) e volume (V) por hectare para árvores com DAP $\geq 35 \mathrm{~cm}$ antes e depois e extraídas durante o corte seletivo para as 195 espécies inventariadas nos 800 hectares.

\begin{tabular}{lccccc}
\hline Parameter & & Unit & Before cutting & After cutting & Removed during harvest \\
\hline $\mathrm{A}$ & & & 27 & 21 & 6 \\
Abundance & $\mathrm{A}_{0}$ & $\mathrm{n}_{\mathrm{i}} / \mathrm{ha}$ & 1 & 1 & 1 \\
$\mathrm{~A}_{+}$ & & & 84 & 70 & 21 \\
$\mathrm{G}$ & & 9.71 & 6.65 & 2.90 \\
Basal area & $\mathrm{G}_{0}$ & $\mathrm{~m}^{2} / \mathrm{ha}$ & 0.27 & 0.26 & 0.23 \\
$\mathrm{G}_{+}$ & & & 25.36 & 20.16 & 9.72 \\
$\mathrm{~V}$ & & & 95.00 & 62.18 & 30.19 \\
Volume & $\mathrm{V}_{0}$ & $\mathrm{~m}^{3} / \mathrm{ha}$ & 2.65 & 2.65 & 1.81 \\
$\mathrm{~V}_{+}$ & & & 271.20 & $210 ., 43$ & 110.74 \\
\hline
\end{tabular}

Note: A: average abundance, $\mathrm{A}_{0}$ and $\mathrm{A}_{+}$: minimum and maximum abundance, $\mathrm{G}$ : basal area, $\mathrm{G}_{0}$ and $\mathrm{G}_{+:}$minimum and maximum basal area, $\mathrm{V}$ : volume, $\mathrm{V}_{0}$ and $\mathrm{V}_{+}$: minimum and maximum volume.

According to the results, after selective cutting, an average of 21 trees per hectare remained, however several HBU's presented up to 70 trees per hectare. The average basal area after selective cutting was $6.65 \mathrm{~m}^{2}$ per hectare, but ranging from 0.26 to $20.16 \mathrm{~m}^{2}$ per hectare in several HBU's; the average volume inventoried was $62.18 \mathrm{~m}^{3}$ per hectare, reaching up to $210.4 \mathrm{~m}^{3}$ per hectare in several HBU's.

Table 1 shows that, on average, six trees had been harvested per hectare; nevertheless, for several HBU's this value reached 21. The average basal area removed was $2.90 \mathrm{~m}^{2}$ per hectare; but in several HBU's this value reached $9.72 \mathrm{~m}^{2}$. The average volume harvested was $30.19 \mathrm{~m}^{3}$ per hectare, but for some HBU's this value reached $110.74 \mathrm{~m}^{3}$.

As an example, table 2 presents the results for 10 species, highlighting the two most frequent ones. It can be observed that Manilkara uberi occurred in $68.25 \%$ of the basic units of one hectare (546 out of 800 ). From these 546 basic units, at least one tree was harvested from 424 basic units (53\% out of 800 ), such that no one tree was removed from $35.13 \%$ of the basic units. Carapa guianensis was present in 446 basic units $(55.75 \%)$. At least one tree was removed from 311 basic units (38.88\%), such that in 287 (35.88\% out of 800) no Carapa guianensis trees were removed, and so on for the other listed species in table 2.

Table 2. Absolute abundance (Aabs) and absolute phytosociological frequency (Ffabs) of some species with $\mathrm{DBH} \geq 35 \mathrm{~cm}$, before, after and harvested during selective cutting.

Tabela 2. Abundância absoluta (Aabs) e frequência fitossociológica absoluta (Ffabs) de algumas espécies com DAP $\geq 35 \mathrm{~cm}$, antes, depois e colhidas durante o corte seletivo.

\begin{tabular}{lcccccc}
\hline \multirow{2}{*}{ Species } & \multicolumn{3}{c}{ Aabs, ni/800ha } & \multicolumn{3}{c}{ Ffabs (\%), 800 hectares } \\
\cline { 2 - 7 } & Before & After & Harvested & Before & After & Harvested \\
\hline Manilkara huberi Ducke (maçaranduba) & 1049 & 362 & 687 & 68.25 & 35.13 & 53.00 \\
Carapa guianensis Aubl. (andiroba) & 955 & 440 & 515 & 55.75 & 35.88 & 38.88 \\
Tabebuia serratifolia (Vah) Nicholson (ipê) & 486 & 164 & 322 & 42.75 & 18.25 & 31.25 \\
Goupia glabra Aubl. (cupiúba) & 363 & 290 & 73 & 33.50 & 26.38 & 8.13 \\
Jacaranda copaia (Aubl.) D. Don (parápará) & 265 & 216 & 49 & 24.13 & 21.00 & 5.00 \\
Trattinnickia rhoifolia Willd. (breu sucuruba) & 223 & 164 & 59 & 21.75 & 17.50 & 6.38 \\
Caryocar brasiliense Aubl. (piquiá) & 192 & 92 & 100 & 20.75 & 10.75 & 11.38 \\
Dipteryxs odorata Aubl.Willd (cumaru) & 159 & 59 & 100 & 17.88 & 6.63 & 11.50 \\
Hymenaea courbaril L. (jatobá) & 112 & 46 & 66 & 13.00 & 5.75 & 7.88 \\
Sextonia rubra Mez van der Werff (louro vermelho) & 106 & 28 & 78 & 10.25 & 3.25 & 7.88 \\
\hline
\end{tabular}


Table 2 shows that, differently from abundance (Aabs), phytosociological frequency is not subjected to addition properties. For example, Manilkara huberi abundance is seen to be 362 (1049 687), while its phytosociological frequency is equal to $35.13 \%(68.25-53 \neq 35.13)$. The phytosociological frequency characteristic demonstrates the importance of its determination for all forest management phases (before, after and harvested), as a component that enables to relate the vital space mechanically altered by the harvest of each species, to the percentage of the areas maintained outside the environmentally damaged zones.

Analyzing the percentage rates in table 3 , it can be seen that before and after selective cutting, the participation of the 10 chosen species, in relation to the other species, ranged from $24.26 \%$ to $10.54 \%$ in abundance, from $27.34 \%$ to $11.21 \%$ in basal area and from $27.63 \%$ to $11.29 \%$ in volume, while other indexes demonstrate that the trees removed by harvest represent $41.25 \%$ of abundance, $45.02 \%$ of basal area and $44.75 \%$ of volume. As to the total, the species harvested represented $21.95 \%$ of abundance, $31.33 \%$ of basal area and $33.76 \%$ of volume.

Table 3. Participation in percentage of abundance, basal area and volume of trees with DBH $\geq 35 \mathrm{~cm}$ of the same species shown in table 2, by level of approach (before, after and harvested), in relation to the 195 species inventoried in the 800 hectares.

Tabela 3. Participação em percentagem da abundância, área basal e volume de árvores com DAP $\geq 35 \mathrm{~cm}$ das mesmas espécies mostradas na tabela 2 (antes, depois e colhidas) em relação às 195 espécies inventariadas nos 800 hectares.

\begin{tabular}{lccc}
\hline Parameter & Before (\%) & After (\%) & Harvested (\%) \\
\hline Abundance & 24.26 & 10.54 & 41.25 \\
Basal area & 27.34 & 11.21 & 45.02 \\
Volume & 27.63 & 11.29 & 44.75 \\
\hline
\end{tabular}

As result of not measuring all the listed trees and several species exclusion in the $100 \%$ inventory, the diameter distribution behavior presented in figure 1 does not show the traditional inverted "J" form found in primary forests. In order to help in the forest diameter structure analysis, histograms were constructed representing the diameter distribution for these 10 species, before and after selective cutting (Figures 2, 3, 4, 5 and 6).

From the diameter distribution for the managed area illustrated in figure $1 \mathrm{a}$, it can be seen that the first two classes show a disagreement in sampling terms, which is in accordance to the previous explanations. This aspect allows observing that during the $100 \%$ inventory only partial measurements were made for diameters below $45 \mathrm{~cm}$. It also demonstrates that on a global aspect, the harvest intensity did not alter the basic distribution profile neither caused apparent unbalance in physical structure. The same effect is confirmed by figure $1 \mathrm{~b}$ where the probability density curve levels suggest that the forest as a whole preserved its diameter structure.

The probability density curves (Figure 1b) highlight the risk of contrasts between the global and local views of the apparent and real effects caused by harvest, even if oriented by the sustainability concept. The forest profile seems to remain in equilibrium, reflecting the "Balanced Forest" condition of Meyer (1952), in which the phytosociological frequency between the successive classes remains approximately constant. But, the real conditions of change in species composition will hardly be observed from an overview, and this is what the diameter distribution results by species had shown; this calls for the need to undertake a more detailed analysis at species level, through which the real alterations could be revealed and their effect quantified.

Figures $2 \mathrm{a}$ and $2 \mathrm{~b}$ show the diameter distribution for the species Goupia glabra (Cupiúba) (Figure 2a) and Jacaranda copaia (Parapará) (Figure 2b), before and after selective cutting. It can be seen that individually, the classes above $50 \mathrm{~cm}$ DBH, with a larger commercial potential use show low levels of abundance reduction, which reflects a lower commercial preference for this species.

As the two pioneer species, it would be desirable to consider their strategic functions in the subsequent growth phases to the selective cutting, mainly in terms of colonization of clearings as this group is one of the few with an active seed bank. The diameter distribution contour (Figure 3a), before and after selective cut, demonstrates an accentuated reduction in the number of trees by DBH class in all 
classes subsequent to the initial minimum diameter cutting limit class. As a consequence, in spite of the remaining trees being about $10 \%$ per class, it is possible to identify a structural break

(a)

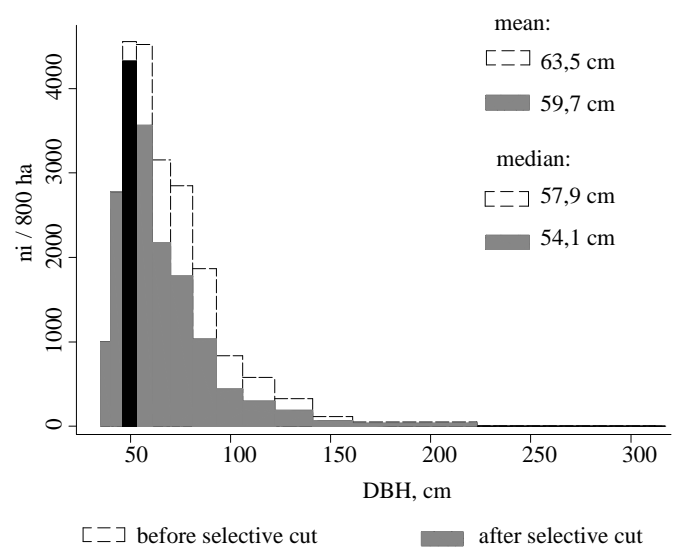

(b)

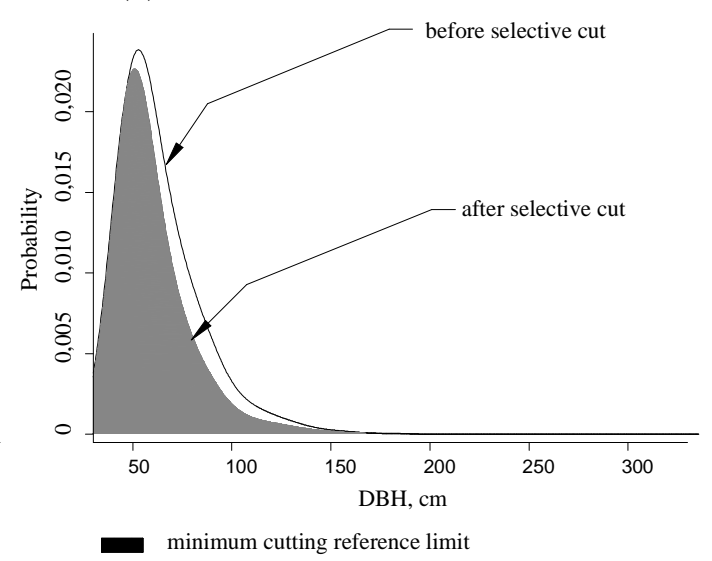

Figure 1. Diameter distribution (a) and probability density curves (b), before and after selective cutting.

Figura 1. Distribuição de diâmetro (a) e curvas de densidade de probabilidades (b) antes e depois do corte seletivo.

(a)

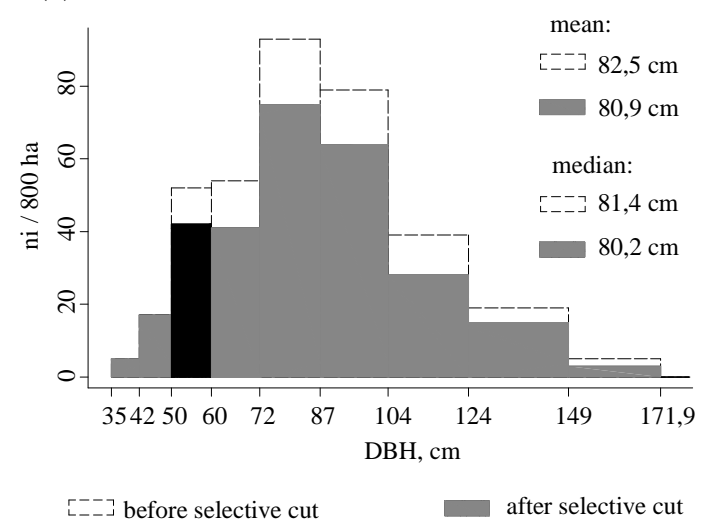

(b)

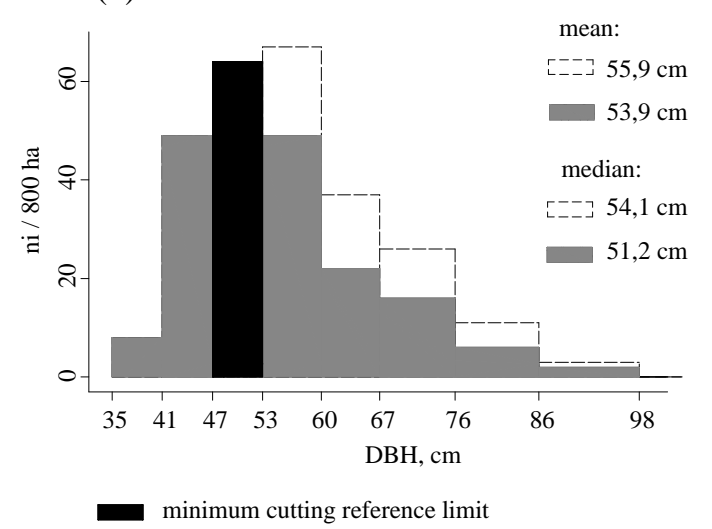

Figure 2. Diameter distribution of two pioneer species: Goupia glabra (a) and Jacaranda copaia (b), before and after selective cutting.

Figura 2. Distribuição de diâmetro de duas espécies pioneiras: Goupia glabra (a) e Jacaranda copaia (b), antes e depois do corte seletivo.

The overlaying of the before and after selective cut diameter distributions shown in figure $3 \mathrm{~b}$ indicates that reduction of the number of trees for the $4^{\text {th }}$ class and for the last two classes was total, what drastically altered the structure of a slow growing species. Although, this situation may be considered as an exception due to the presence of remaining trees in the minimum DBH cutting limit class and in two contiguous intermediary classes at levels meeting the 10\% required by the Forest Code (BRASIL, 1965), the adopted procedure in this case has to be revised by those responsible for regulating, controlling, inspecting and authorizing the execution of forest management in the Amazon.

Figure $4 \mathrm{a}$, shows that the resulting distribution after selective cutting presents high alteration levels in comparison to the initial structure. Although in almost all classes, with the exception of the last one, a minimum of $10 \%$ of the inventoried stock was maintained; even considering that this is the first cutting cycle and by intending to publicize the principles and practices of sustainable forest management 
in the Amazon, the current picture of this reality cannot guarantee a satisfactory recuperation of these species over the next few cutting cycles.

(a)

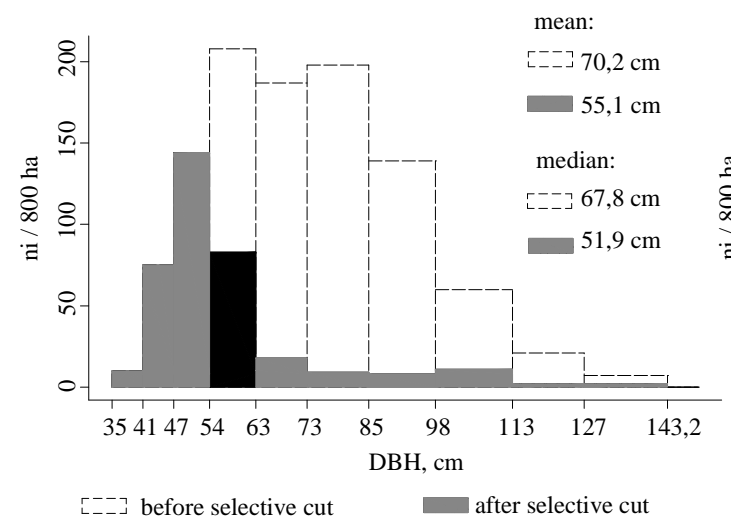

(b)

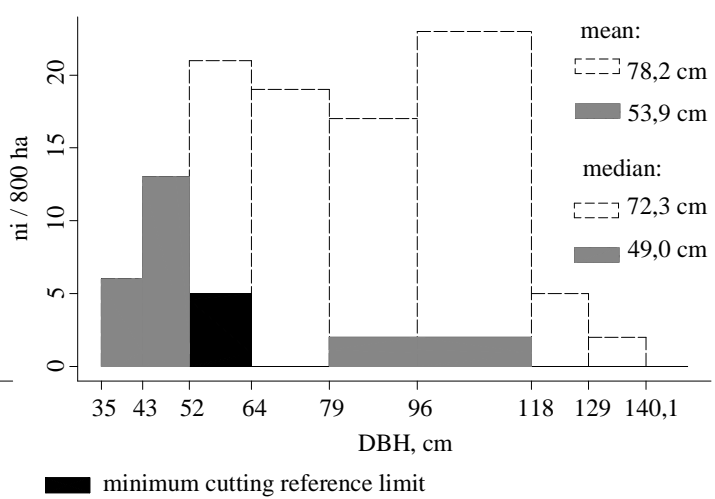

Figure 3. Diameter distribution of two slow growth climax species: Manilkara huberi (a) and Sextonia rubra (b), before and after selective cutting.

Figura 3. Distribuição de diâmetro de duas espécies clímax de crescimento lento: Manilkara huberi (a) e Sextonia rubra (b), antes e depois do corte seletivo.

Dipteryx odorata (Figure 4b) shows a well balanced structure between classes before harvesting, but, on the other hand, a total reduction of six trees in the sixth class as a consequence of selective cutting. In relation to all remaining trees, the distribution demonstrates a balance loss in the subsequent classes to a minimum cutting diameter, which cannot be favorable to its growth dynamics in the phase before the second cutting cycle.

(a)

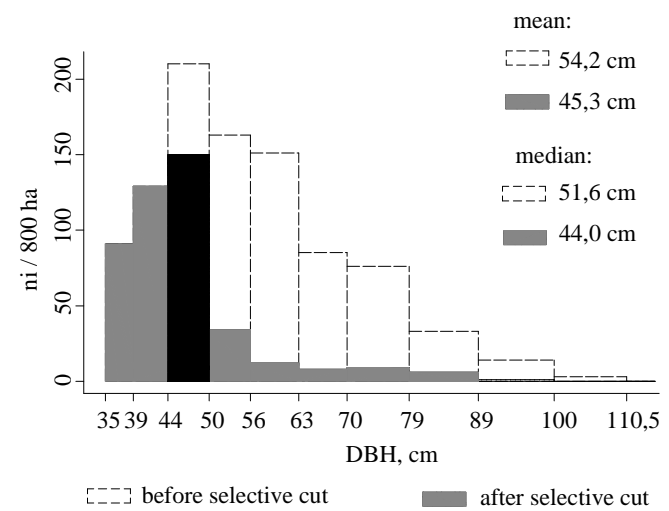

(b)

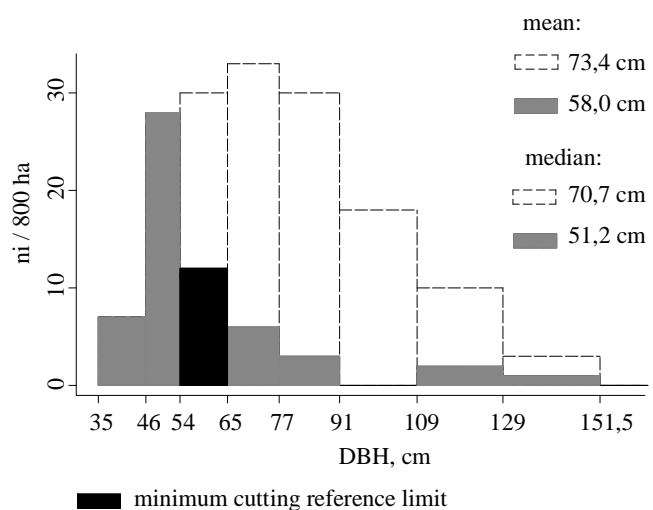

Figure 4. Diameter distribution of two fast growth climax species: Carapa guianensis (a) and Dipteryx odorata (b), before and after selective cutting.

Figura 4. Distribuição de diâmetro de duas espécies clímax de rápido crescimento: Carapa guianensis (a) e Dipteryx odorata (b) antes e depois do corte seletivo.

The distribution profile after selective cutting (Figure 5a) differs completely from that observed before selective cutting. Reasonable conditions were not established for the recuperation of this species because the structure changed at levels comparable to those observed; this makes stock restoration much more difficult for commercial classes.

The diameter distribution pattern (Figure 5b) highlights the total reduction of the number of trees in the last class, after selective cutting. In spite of this, no serious consequences are expected, as the wide 
diameter range of this species allows it to maintain about $50 \%$ of the stock of the second last class and ensures good balanced conditions in the extreme classes. The distribution pattern after selective cutting demonstrates that the stock reduction in the intermediary classes was quite constant, perhaps due to the low priority for this species in commercial terms.

(a)

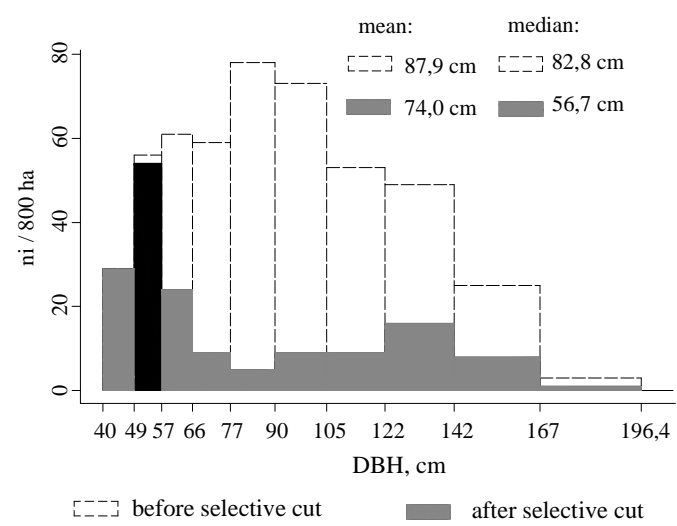

(b)

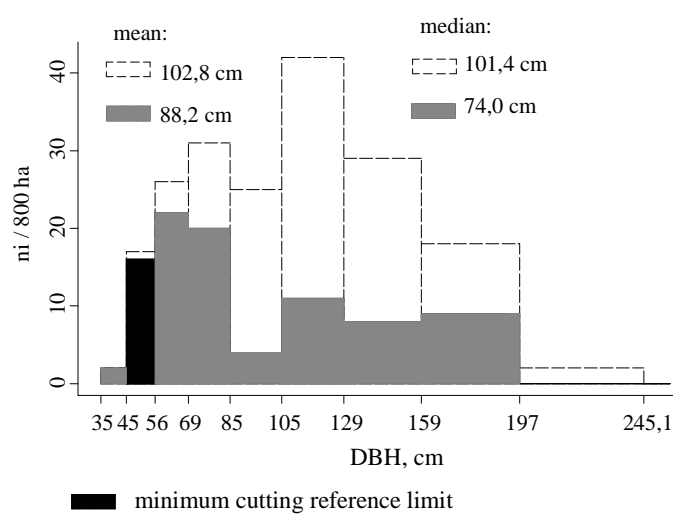

Figure 5. Diameter distribution of two fast growth climax species: Tabebuia serratifolia (a) and Caryocar brasiliense (b), before and after selective cutting.

Figura 5. Distribuição de diâmetro de duas espécies clímax de rápido crescimento: Tabebuia serratifolia (a) e Caryocar brasiliense (b), antes e depois do corte seletivo.

The diameter distribution characterized by figure $6 a$ demonstrates that before selective cutting, Hymenaea courbaril (jatobá) had a high abundance in the central diameter classes. The reduction of the tree stock (Figure 6a) was more intense in these classes. In spite of the stock levels in accordance to the $10 \%$ foreseen in the Forest Code, except for the last class (zero stock), and distribution of the remaining trees, we cannot assure that the number of individuals with these characteristics will be enough before selective cutting in the second cutting cycle.

The analysis of figure $6 \mathrm{~b}$ allows to observe that the diameter distribution of the remaining trees, besides maintaining good balance, kept the same profile as before selective cutting. With such characteristics, it can be said that as a reference prototype for the first cutting cycle, the current case fits into a feasible alternative for executing and control aiming to carry out sustainable forest management.

(a)

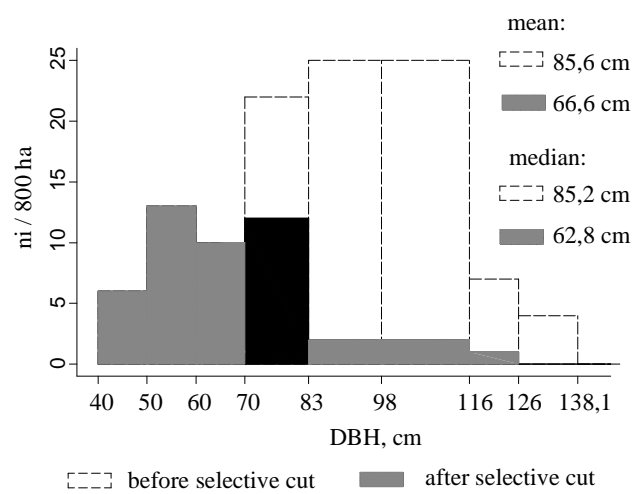

(b)

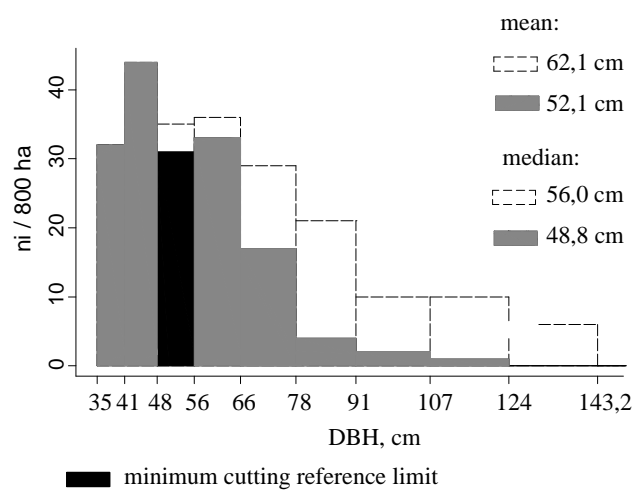

Figure 6. Diameter distribution of two climax species: slow growth Hymenaea courbaril (a) and fast growth Trattinnickia rhoifolia (b), before and after selective cutting.

Figura 6. Distribuição de diâmetro de duas espécies clímax: Hymenaea courbaril (a) crescimento lento e Trattinnickia rhoifolia (b) crescimento rápido, antes e depois do corte seletivo. 
Figure 7 shows that with reduction in basal area at all levels of diameter range, using as reference cutting lower limit $\mathrm{DBH} \geq 50 \mathrm{~cm}$, a structure profile was maintained after selective cutting, which is similar to the profile before selective cutting. Considering that the relation between the basal area and the $\mathrm{DBH}$, as shown in figure 7, involves a primary managed forest, the basal area removal was more critic in the five first classes subsequent to the cutting limit up to an approximate $100 \mathrm{~cm} \mathrm{DBH}$, where the harvested basal areas apparently reached lower levels.

In spite of the limitations inherent to this kind of analysis, two important issues should be highlighted: i) the lowering of the basal area curve demonstrates that there was a strong intervention related to the one that would be theoretically expected for the first cutting cycle and ii) the regulation of shape of the basal area related to DBH class can be indicated as the most positive factor to be observed (Figure 7); the maintenance of a structure similar to the original profile is fundamental to aid the natural regeneration control process.

The inclusion of graphs in the Annual Operating Plan (POA - plano operacional anual), for the 10 most important species listed in forest management, as applied in the current study, that is, before and after selective cutting, beside identifying elements for sustainable management, leads to create and keep a desirable structure, compatible with the permanence of well distributed adult trees in the commercial classes avoiding breaks or unnecessary ruptures in the profile of the remaining forest.

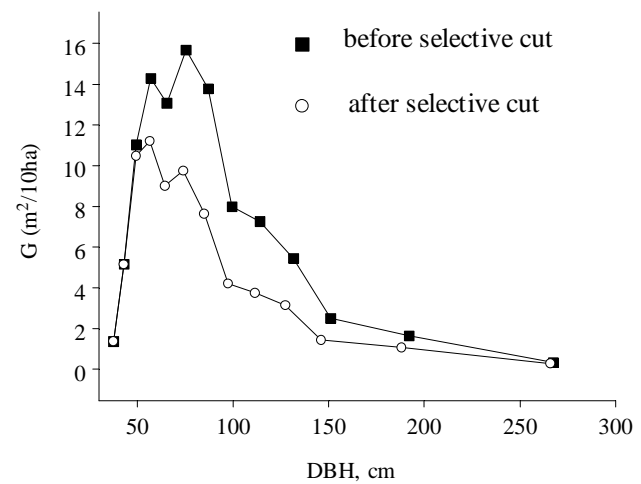

Figure 7. Basal area for the 195 species inventoried in the 800 hectares by DBH class in each 10 hectare unit.

Figura 7. Área basal para as 195 espécies inventariadas nos 800 hectares por classe de DAP em cada unidade de 10 hectares.

From a global point of view, the results suggest that Meyer's "Balanced Forest" concept was achieved even using inadequate management practices for some species. This fact can result in serious consequences for the sustainability during the next cutting cycles for those species that present diameter structure hampered by the cutting intensity.

Carvalho (1981) in his research in a 35 hectares census into Tapajos National Forest, located at the kilometer 57 of the Santarém - Cuiabá road, found an average frequency of 40.69 trees per hectare and volume of 134.36 cubic meters per hectare for trees with DBH above $35 \mathrm{~cm}$. In this research, working on 800 hectare area, the variation ranged from 27 to 84 trees per hectare and from 95 to $271 \mathrm{~m}^{3}$ per hectare. These results show some consistency in values between the two surveys. However, while working at the species level, one can observe some differences in the shape of the diameter distribution curve for some species between these two surveys. This is surely likely to happen, since the two study areas are located in different points of the Tapajos National Forest as well as the fact that the area of the current study has covered 800 hectares, while the area focused by Carvalho (1981) had only 35 hectares.

Analysis of the histograms of diameter distribution observed prior to harvest, considering all species, reveals that the curve shape approaches to the balanced distribution identified by Meyer (1952). This same configuration was also observed by Barros et al. (1979), Carvalho (1981) and Silva (1989), for an area of 35 hectares in the Tapajos National Forest. The same type of distribution was reported in other researches carried on the Amazon forest, such as those from Azevedo et al. (2007) in Jari, Souza (2004) 
in ZF2 INPA, Vasconcelos (2003) in the State of Acre, and others.

However, when dealing with the distribution at species level, several of them had a diameter distribution tending to the unimodal shape, with several degrees of unimodality, as demonstrated in the pioneering work of Heinsdijk and Bastos (1963) in upland forests along the Amazon River. This aspect was also noted by Carvalho (1981) in the Tapajos National Forest, where this study was also carried out. Although the general shape of the diameter distribution curves by species can be considered identical, there are differences between this study and the mentioned other ones. While Carvalho (1981) research was based on a 35 hectares census, the results obtained in this research came from the census of 800 hectares in the same Tapajos National Forest, which accounted for a better representation of the results.

In his research in the tropical forestry experimental station of National Institute of Amazonian Research - (INPA), Souza (2004) noted that the diameter structure of the forest followed the typical shape of inverted "J", for all treatments of basal area reduction before and after cutting.

Comparing the diameter distribution resulting from experimental areas that were subjected to various degrees of reduction of basal area, Souza (2004) observed that, in general, there were no significant differences among different treatments, except between the control treatment (T0) and treatment with $69 \%$ of basal area reduction (T3).

In this research, the exploitation was done in an area of 800 hectares, by a forestry company, aiming to follow the rules of IBAMA. The diameter distribution curves for all species and for individually species, before and after harvesting, clearly reveals changes in the curves shape and number of trees removed, with examples for some pioneer species, for slow growing climax and for fast growth climax species. Such details were not covered in other studies.

\section{CONCLUSIONS}

- The intensity of selective cutting only leads to a satisfactory diameter structure change in a few cases, such that, in the majority of cases observed, a balanced abundance reduction $\left(\mathrm{n}_{\mathrm{i}} / \mathrm{ha}\right)$ was not carried out within each diameter class, with the most critical effects resulting from the elimination of diameter classes for the following species: Sextonia rubra and Dipteryx odorata.

- The assessment of the phytosociological frequency for each species associated to the individual analysis of the diameter classes, before and after a selective cutting, could lead to the organization and ordering for a better spatial arrangement of the individuals that would be removed from the forest.

- The analysis and interpretation of graphic techniques results before and after selective cutting are important support for management actions planning, as revealed to the 10 most important tree species.

\section{REFERENCES}

AZEVEDO, C. P.; SANQUeTTA, C. R.; SILVA, J. N. M.; MACHADO, S. A.; SOUZA, C. R.; OLIVEIRA, M. M. Predição da distribuição diamétrica de uma floresta manejada experimentalmente através de um sistema de equações diferenciais. Acta Amazonica, v. 37, p. 521 - 532, 2007.

BARROS, P. L. C.; MACHADO, S. A.; BURGER, D.; SIQUEIRA, J. D. P. Comparação de modelos descritivos da distribuição diamétrica em uma floresta tropical. Revista Floresta, v. X, n. 2, p. 19 - 32, 1979 .

BRASIL. Lei $\mathrm{n}^{0} 4.771$ de 15 de setembro de 1965: institui o Novo Código Florestal Brasileiro. Disponível em: <http://www.planalto.gov.br/ccivil_03/leis/14771.htm>. Acesso em: 15/08/2011.

CARVALHO, J. O. P. Distribuição diamétrica de espécies comerciais e potenciais em floresta tropical úmida natural na Amazônia. Belém, EMBRAPA-CPATU, 1981. 34 p. (EMBRAPA-CPATU. Boletim de Pesquisa, 23).

CUNHA, U. S. Análise da estrutura espacial horizontal de uma floresta de terra firme da Amazônia. 126 p. Tese (Doutorado em Ciências Florestais) - Universidade Federal do Paraná, Curitiba, 2003. 
CUNHA, U. S.; MACHADO, S. A.; HOSOKAWA, R. T.; FIGUEIREDO FILHO, A. Um novo método para agrupar dados em classes com amplitudes variáveis. In: $8^{\circ}$ Congresso Florestal Brasileiro, 2003, São Paulo, 13 p.

FINOL, U. H. Estudio silvicultural de algumas especies comerciales en el bosque universitario "El Caimital" Estado Barinas. Revista Forestal Venezolana, Merida, v. 12, n. 10 - 11, p. 17 - 63, 1964.

FRANCEZ, L. M. B.; CARVALHO, J. O. P.; JARDIM, F. C. da S.; QUANZ, B.; PINHEIRO, K. A. O. Efeito de duas intensidades de colheita de madeira na estrutura de uma floresta natural na região de Paragominas, Pará. Acta Amazonica, v. 39, p. 851 - 864, 2009.

HEINSDIJK, D.; BASTOS, A. M. Inventários florestais na Amazônia. Rio de Janeiro. Ministério da Agricultura, Serviço Florestal - Setor de Inventários Florestais. 1963, 100 p. (Boletim n. 6).

INSTITUTO BRASILEIRO DO MEIO AMBIENTE (IBAMA). Instrução normativa $\mathbf{n}^{\mathbf{0}} \mathbf{4}$, de $\mathbf{4}$ março de 2002. Diário Oficial no 45, de 7 de março de 2002. Dispõe: Capítulo I - Da exploração das florestas da Bacia Amazônica; Capítulo II - Das sanções administrativas e penais; Capítulo III. Das disposições gerais e transitórias Brasília. Disponível em: 〈http://www.ibama.gov.br/fauna/legislacao/in_04_02.pdf〉. Acesso em: 24/02/2012.

. Plano de manejo florestal da Floresta Nacional do Tapajós, Pará, Brasil. Belém, 1997, 109 p.

JARDIM, F. C. S; HOSOKAWA, R. T. Estrutura da floresta equatorial úmida da estação experimental de silvicultura tropical do INPA. Acta Amazônica, n. 16/17, p. 411 - 507, 1987.

MEYER, H. A. Structure, growth and rain in balanced uneven-aged forests. Journal of Forestry, n. 50, p. $85-92,1952$.

SILVA, J. N. M. The behavior of the tropical rain forest of the Brazilian Amazon after logging. Oxford: Oxford Forestry Institute, 1989. 302 p.

SOUZA, M. E. R. F. de. Influência de diferentes níveis de exploração na distribuição diamétrica de uma floresta tropical úmida. 55 f. Dissertação (Mestrado em Biologia Tropical e Recursos Naturais) Instituto Nacional de Pesquisas da Amazônia/Universidade Federal do Amazonas, Manaus. 2004.

UMAÑA, C. L. A.; ALENCAR, J. C. Distribuições diamétricas da floresta tropical úmida em uma área no município de Itacoatiara - AM. Acta Amazonica, v. 28, n. 2, p. 167 - 190, 1998.

VASCONCELOS, S. S. Dinâmica de uma floresta explorada seletivamente no projeto de colonização Pedro Peixoto na Amazônia Ocidental. 71 f. Dissertação (Mestrado em Biologia Tropical e Recursos Naturais) - Instituto Nacional de Pesquisas da Amazônia/Universidade Federal do Amazonas, Manaus, 2003.

VASCONCELOS, S. S.; HIGUCHI, N.; OLIVEIRA, M. V. Projeção da distribuição diamétrica de uma floresta explorada seletivamente na Amazônia Ocidental. Acta Amazonica, v. 39, p. 71 - 80, 2009. 
